\title{
The Change of Investment Behavior during Covid-19 Pandemic in Indonesia Stock Market
}

\author{
Farida Komalasari ${ }^{1}$, Lucia Elshadai Lastria Monita Manik ${ }^{2}$, Eko Ganiarto ${ }^{3}$ \\ \{farida_k@president.ac.id ${ }^{1}$ \} \\ President University, Indonesia ${ }^{1,2,3}$
}

\begin{abstract}
The emergence of the Covid-19 Pandemic has made the Indonesian stock market unstable. Investment behavior in a person can change at an unknown time. By incorporating planned behavior theory and perceived risk theory, this research analyzed the change of investment behavior from six different variables. Therefore, the purpose of this research is to compare the investors' behavior before and during Covid-19 Pandemic in Indonesia Stock Market. Those are investor's attitudes, subjective norms, perceived behavioral, perceived risk, behavioral intention, and actual behavior before and during the Covid-19 pandemic in Indonesia Stock Market. The data was analyzed using the paired sample t-test. The results stated that investor's investment behavior significantly changes in a period of before Covid-19 Pandemic and during Covid-19 Pandemic. It happened because of any information obtained about the instability of the current stock market, the influence of people around who began to reduce investment activity in the stock market, a lack of self-control in an individual, and a greater risk of losing money.
\end{abstract}

Keywords: Planned Behavior Theory, Perceived Risk Theory, Investment Behavior, Covid-19, Indonesia

\section{Introduction}

Quoting from Lestari (2020), many people want to get financial freedom as young as possible. There are several strategies to achieve financial freedom, one of which is doing investment. There are many investment instruments; one of them is investing in a capital market. Indonesia Stock Exchange (IDX) recorded 2.48 million investors in 2019, increased by 53 percent compared to 2018. Meanwhile, until May 2020, the number of investors reached 2.81 million, and stock investors reached 1.19 million [1].

Increasing the number of investors in Indonesia leads to the growth in Indonesia's share prices. The Jakarta Composite Index touched the highest level in 6,547.88 on February 6, 2019 and the lowest was 5,826.87 on May 17, 2019 [2]. At the end of 2019 Jakarta Composite Index was 6.299,53 and The Minister of Finance, Sri Mulyani hoped that Jakarta Composite Index will grow in 2020 [3].

However, since the beginning of 2020, the Indonesia economy has declined. This reduction occurred because the influenced of Corona Virus or Covid-19 that makes various activities obstructed. The Indonesia capital market gets an impact from this pandemic as well. One of the effects is Jakarta Composite Index goes down continuously as much as 27,95 percent at the end of March 2020 [4]. Because of this issue, many foreign and local investors quit from capital market. Investors sold their stock, and then give the impact on the decreasing of the stock price. 
This shows that there is an investment behavioral change in Indonesia Stock Market. The purpose of this research is to compare the investors' behavior before and during Covid-19 Pandemic in Indonesia Stock Market. Based on planned behavior theory and perceived risk theory, the investment behavior can be seen from investor's attitude, investor's subjective norms, investor's perceived behavioral control, investor's perceived risk, investor's behavioral intention, and investor's actual behavior [5][6][7][8].

Attitude refers to the extent to which a person has thoughts or evaluations about interesting behavior given whether it is beneficial or not [7]. Attitudes can be identified as an assessment of results relating to certain behaviors and supported by previous experience [9]. In terms of finance, attitude refers to the individual's state of mind, feelings, and opinion regarding the finance [10]. In this research, investor's attitude is defined as the individual's state of mind toward investment idea that can be influenced by his previous investment experience.

Subjective norms reflect individual perceptions of how a behavior should be done or not that comes from the thoughts of others [7]. Subjective norms are part of the external factor of the individual investor because it arises from the other investors' perception [11]. In this research, subjective norms are defined as how the influence of external factors, include family, friends, people around, and news, on the individual investment behavior.

Perceived behavioral control can be defined as the perceived ease or adversity on undertaking the behavior by the individual [12]. Perceived behavioral control refers to the control belief which relates to the surrounding where individual may lack complete control over his/her behavior [7]. Meanwhile, perceived behavioral control arises based on individuals' beliefs or past experiences towards performing the behavior obtained by themselves or others [8]. In this research, investor's perceived behavioral control is defined as how the individual investor on controlling his/her investment activity.

Perceived risk refers to the extent to which the investors feel the uncertainty or consequences of investing in the stock market [13]. Perceived risk is defined as the investors' perception of negative consequences possibility after receiving an object or the extent to which investor perceived loss after receiving the object [14]. Perceived risk can be defined as the investors' loss expectation that will be occurring when the investor doing the investment in the stock market [15]. In this research, perceived risk is measured by using investor's perception on price volatility, uncomfortable situation, probability of loss, and low return possibility.

Behavioral intention is defined as the degree and tendency of the investor to keep doing investment. It shows the extent to which an investor formulates plans to execute or not investment transactions for the future [16][17]. Behavioral intention is considered as the investors' loyalty regarding the investment activities to recommend others because they have obtained the advantages from the investment [18]. In this research, investor's behavioral intention is measured by how frequent the investor will invest, how big the investors' intention and encourage others to invest in a stock market in the near future.

Actual behavior refers to the process and activities when individuals are searching, purchasing, using, and evaluating of the particular products or services [19]. Actual behavior can be defined as the manifestation of the thought and observation to which an individual performs or reject perform that is obtained [7]. Actual behavior can be defined as the result of the individual's evaluation after through the planning process to take action [8]. In this research, investor's actual behavior is defined as the investor's stock purchasing after searching, evaluating, and identifying a particular stock. 
Investment behavior is influenced by internal and external factors [20]. The internal factors come from the personal characteristics of an individual investor. Including the internal factors are individual risk perception and information perception, investment expected return [21][22][23], investors' confidence to face the economy and stock market stability and the worry of getting a loss [24]. Meanwhile, the external factors come from outside, such as the current economy, the performance of a particular stock, and information from the market [25], the strength or stability of the economy, the media that spread regarding stock market information, the political stability, and the government policies toward business [26], the financial stability of the company [27], the expectation of other investors or groups [28], and liquidity of the stock [24], and information about stock price movement (IHSG) [26].

Those factors are certainly different before and during Covid-19 Pandemic. So, the consequences can be predicted that there is a change on investment behavior before and during Covid-19 Pandemic. Therefore, this research analyzes the difference of investment behavior before and during Covid-19 Pandemic.

This study has three research gaps. In terms of the theoretical gap, the previous study used 5 variables, attitude, subjective norms, perceived behavioral control, behavioral intention, and actual behavior [7]; while this research used 6 variables by adding up one new variable, perceived risk. In terms of the methodological gap, the previous research was using multigroup CFA to analyze the research variables [5] and Structural Equation Modeling (SEM) [7]; while this research used a paired t-test analysis to compare the data of investment behavior before and during Covid-19. In terms of empirical gap, the previous studies were done in the UK and Greece [5], and in India [7]; while this research was done in Indonesia.

\section{Method}

This theoretical framework can be seen in Figure 1. According to the framework, the hypotheses are:

$\mathrm{H}_{0 \mathrm{i}}$ There is no difference of $\mathrm{i}$ between before and during Covid-19 Pandemic.

$\mathrm{H}_{1 \mathrm{i}}$ : There is difference of $\mathrm{i}$ between before and during Covid-19 Pandemic.

Where $\mathrm{i}$ is the six of investment behavior's variables as shown in Figure 1.

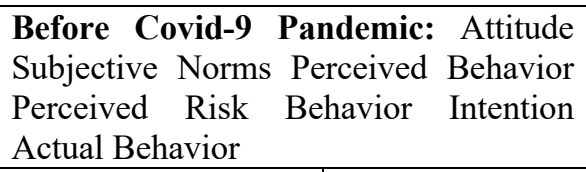

During Covid-9 Pandemic: Attitude Subjective Norms Perceived Behavior Perceived Risk Behavior Intention Actual Behavior

\section{Paired Sample T-Test}

Fig. 1. Theoretical Framework

This research was conducted by using quantitative research with primary data. The data were collected by spreading the questionnaire, which consists of 4 sections. Those are introduction, screening section, demography profile, and variables' measurements. The fourth section has 30 statements, which come from 5 statements for 6 investment behavior. The item statements use 7 Likert scale, from 1 (strongly disagree) to 7 (strongly agree). There are 2 
answer columns for each statement, which the first for before Covid-9 Pandemic and the second for during Covid-19 Pandemic.

The population is the individual stock investors in Indonesia who have ever done investment before and during Covid-19 Pandemic. The number of respondents is 310 , selected by using non-probability sampling, which is snowball sampling.

Paired sample t-test is used for hypothesis testing. Paired sample t-test is a statistical technique that is used to compare the same population (subject, object, and individual) but with different treatment [29]. In this research, the different treatment is before Covid-19 Pandemic and during Covid-19 Pandemic.

\section{Result and Discussion}

The respondents in this research are investors who have ever done investment before and during pandemic Covid-19 in Indonesia. Total of respondents examined are 310 respondents, who $35.2 \%$ (109 respondents) are female and 64.8\% (201 respondents) are male. It is proved that male is more adventurous in investment activities [30]. The majority of the respondents are between 21-35 years old (almost 80\%). The most occupation of the respondents is students (43.9\%), followed by employee (43.5\%), entrepreneur $(8.1 \%)$, and others occupation (4.5\%). Based on the respondents' last education, most of the respondents' last education is Bachelor Degree/S1 (48.1\%) of percentage, followed by Senior/Vocational School (SMA/SMK) (39.4\%), Diploma (6.5\%), Master Degree (5.8\%), and the last is Doctor degree $(0.3 \%)$.

Table 1 shows the mean differences of all investment behavior variables, between before and during Covid-19. There is the decreasing of almost all investment behavior, except perceived Risk (PR). The largest decreasing of investment behavior is in Pair 1, that is the difference of Attitude (AT) in investment (-0.859), followed by Pair 3 (Perceived Behavior/PB, -0.846), Pair 5 (Behavior Intention/BI, -0.812), Pair 6 (Actual Behavior/AB, 0.561), Pair 2 (Subjective Norms/SN, -0.450). Especially for Pair 4 (Perceived Risk/PR) there is an increasing as much as +0.429 .

Table 1. Paired Sample Test Result

\begin{tabular}{|c|c|c|c|c|c|}
\hline \multirow{2}{*}{ Pair } & \multirow{2}{*}{ Difference } & \multicolumn{2}{|c|}{ Paired Difference } & \multirow{2}{*}{$\mathrm{t}$} & \multirow{2}{*}{$\begin{array}{c}\text { Sig. } \\
\text { (2-tailed) }\end{array}$} \\
\hline & & Mean & Std. Deviation & & \\
\hline $\mathrm{P}-1$ & AT-Before - AT-During & -0.850 & 1.550 & -9.653 & 0.000 \\
\hline $\mathrm{P}-2$ & SN-Before - SN-During & -0.450 & 1.069 & -7.418 & 0.000 \\
\hline $\mathrm{P}-3$ & PB-Before - PB-During & -0.846 & 1.316 & -11.317 & 0.000 \\
\hline $\mathrm{P}-4$ & PR-Before - PR-During & -0.429 & 1.133 & +6.664 & 0.000 \\
\hline $\mathrm{P}-5$ & BI-Before - BI-During & -0.812 & 1.506 & -9.491 & 0.000 \\
\hline P-6 & AB-Before - AB-During & -0.560 & 1.147 & -8.594 & 0.000 \\
\hline
\end{tabular}

Based on the result of paired sample test analysis, it shows that there are significant differences of all investment behaviors (Attitude, Subjective Norms, Perceived Behavior, Perceived Risk, Behavior Intention and Actual Behavior), between before and during Covid19 Pandemic. It can be seen from the significant value in last column in Table 1.

Since all the significant value (Sig. 2-tailed) in Table 1 are 0.000 or less than 0.05 , it means that there are significant differences in investment behavior between before and during 
Covid-19 Pandemic. So, the null hypothesis which states that there is no difference of investment behavior between before and during Covid-19 Pandemic must be rejected.

Table 1 shows there is the decreasing of investor attitude (AT) in investing in stock market during Covid-19 Pandemic. This is the realistic reason of the investor to avoid investing in any investment in the bad business situation during pandemic. Before pandemic, investors think that doing investment is a good idea to get return; but during pandemic is not a good idea because the market is unstable. This result is supported by previous research stated that the favorable and convenience of the investor when doing investment depend on the availability of information which is existing in the market [7].

In term of investors' subjective norms, the result shows that there are different influence of family, friends, and people around on investors' decision making before and during Covid19 Pandemic. Subjective norms decrease during pandemic. When a subjective norm is increasing, the interest of investors in doing investment will increase; when subjective norms are decreasing, the interest of investors in doing investment will diminish [11]. So, maintaining a good relationship with family, friends, and people around is needed to increase the interest for doing investment.

The statistical analysis shows that investors' perceived behavioral control decreases significantly during the pandemic. As mentioned in the past research that weak of self-control cannot deals with the situation and desire of investors [9]. It might because they are panic with the market situation during pandemic.

Another variable is perceived risk. The result shows that investors' perceived risk increases during the pandemic. This indicates there is changing in investors' mind, feel, and opinion about the investment risk in stock market before and during Covid-19 Pandemic. It is very logic, since investors feel that doing investment in stock market during pandemic is riskier than before. When the market is unsteady the risk that will be perceived will be advance as well.

The next variable is behavior intention. The investors' behavior intention is significantly decrease during the pandemic. This result indicates that investors have negative perceptions regarding investment in stock market during pandemic. It is proved by previous research, mentioned that the more investors have a positive perception, the more they intend to engage in investment, and vice versa [31].

Lastly is actual behavior. The result shows that the investors' actual behavior significantly decreases during the pandemic. It can be the result of decreasing on behavior intention. On the other side, decreasing on investors' attitude, subjective norm, and perceived behavior; and increasing on perceived risk may cause the decreasing on behavior intention. A further study is needed to prove that there is any significant influence of attitude, subjective norm, perceived behavior and perceived risk to behavior intention; and behavior intention towards actual behavior.

\section{Conclusion}

This research concluded that the investors' investment behavior significantly different between before and during Covid-19 Pandemic. The difference can be seen from the six variables, those are investor's attitude, subjective norms, perceived behavior, perceived risk, behavioral intention, and actual behavior.

There is significant change on investment behavior before and during Covid-19 Pandemic. Before Covid-19 Pandemic, the attitude, subjective norms, perceived behavioral, 
behavioral intention, and actual behavior have average high score (above 5 from 7 scale). Investors believe that information or activities that occur in the market do not really interfere their investment behavior. Conversely, during Covid-19 Pandemic, the average score is low (below 5 from 7 scale). When the Covid-19 pandemic occurs, investors feel distracted by their thoughts and desires to invest due to unstable markets. Furthermore, it decreases in investor behavior in terms of attitude, subjective norms, perceived behavioral control, perceived risk, behavioral intention, and actual behavior.

Based on the research result, learning from the Covid-19 Pandemic, investors should be more careful. The decrease in stock prices during pandemic makes a change in investors' behavior because they panicked about the situation. It also encourages government to have initiatives or ways to stabilize the economy because pandemic actually changes the investor's behavior. This research result inspires another research to answer is there any different model of investor's actual behavior before and during Covid-19 Pandemic, with the same or different variables used in this research.

\section{References}

[1] K. Safitri, "Sepanjang 2019, Jumlah Investor Pasar Modal Indonesia Tembus 2,48 Juta," Kompas.com, $2020 . \quad$ [Online]. Available: https://money.kompas.com/read/2020/06/30/151729226/sepanjang-2019-jumlah-investor-pasarmodal-indonesia-tembus-248juta\#: :text=Sepanjang\%25202019\%252C\%2520Jumlah\%2520Investor\%25\%252020Pasar\%2 520Modal\%2520Indonesia\%2520Tembus\%25202\%252C48\%2520Juta,Kompas.com $\% 2520 \% 252 \mathrm{D} \% 252030 \&$ text $=\% 2520$ JAKART.

[2] W. T. Rahmawati, "Tahun 2019 tinggal sebulan, IHSG termasuk indeks berkinerja terburuk," Kontan.co.id, 2019. [Online]. Available: https://investasi.kontan.co.id/news/tahun-2019-tinggalsebulan-ihsg-termasuk-indeks-berkinerja-terburuk-1?page $=1$.

[3] A. M. Karunia, "Penutupan IHSG akhir tahun, harapan Sri Mulyani pupus," Kompas.com, 2019. [Online]. Available: https://money.kompas.com/read/2019/12/30/170000326/penutupan-ihsgakhir-tahun-harapan-sri-mulyani-pupus-.

[4] K. Intan, "Wabah corona membayangi, simak prediksi IHSG hingga akhir tahun ini," Kontan.co.id, 2020. .

[5] E. Palamida, S. Papagiannidis, and D. Xanthopoulou, "Linking young individuals' capital to investment intentions: Comparing two cultural backgrounds," Eur. Manag. J., vol. 36, no. 3, pp. 392-407, 2018.

[6] X. Yang, K. Zhao, X. Tao, and E. Shiu, "Developing and validating a theory-based model of crowdfunding investment intention-Perspectives from social exchange theory and customer value perspective," Sustainability, vol. 11, no. 9, p. 2525, 2019.

[7] R. K. Raut and N. Das, "Individual investors' attitude towards online stock trading: some evidence from a developing country," Int. J. Econ. Bus. Res., vol. 14, no. 3-4, pp. 254-267, 2017.

[8] R. S. Paramita, Y. Isbanah, T. M. Kusumaningrum, M. Musdholifah, and U. Hartono, "Young investor behavior: implementation theory of planned behavior," Int. J. Civ. Eng. Technol., vol. 9, no. 7, pp. 733-746, 2018.

[9] M. Kashif, A. Zarkada, and T. Ramayah, "The impact of attitude, subjective norms, and perceived behavioural control on managers' intentions to behave ethically," Total Qual. Manag. Bus. Excell., vol. 29, no. 5-6, pp. 481-501, 2018.

[10] M. Ameliawati and R. Setiyani, "The influence of financial attitude, financial socialization, and financial experience to financial management behavior with financial literacy as the mediation variable," KnE Soc. Sci., pp. 811-832, 2018.

[11] E. Taufiqoh, N. Diana, and J. Junaidi, "Pengaruh Norma Subjektif, Motivasi Investasi, 
Pengetahuan Investasi, Persepsi Return dan Literasi Keuangan Terhadap Minat Mahasiswa Berinvestasi Saham di Pasar Modal," J. Ilm. Ris. Akunt., vol. 8, no. 05, 2019.

[12] J. Lortie and G. Castogiovanni, "The theory of planned behavior in entrepreneurship research: what we know and future directions," Int. Entrep. Manag. J., vol. 11, no. 4, pp. 935-957, 2015.

[13] N. M. Kassim and T. Ramayah, "Perceived risk factors influence on intention to continue using Internet banking among Malaysians," Glob. Bus. Rev., vol. 16, no. 3, pp. 393-414, 2015.

[14] Q. Zhao, C.-D. Chen, J.-L. Wang, and P.-C. Chen, "Determinants of backers' funding intention in crowdfunding: Social exchange theory and regulatory focus," Telemat. Informatics, vol. 34, no. 1, pp. 370-384, 2017.

[15] M. Meyliana and E. Fernando, "The Influence of Perceived Risk and Trust in Adoption of FinTech Services in Indonesia," CommIT (Communication Inf. Technol. J., vol. 13, no. 1, pp. 31-37, 2019.

[16] A. A. Alalwan, Y. K. Dwivedi, and M. D. Williams, "Customers' intention and adoption of telebanking in Jordan," Inf. Syst. Manag., vol. 33, no. 2, pp. 154-178, 2016.

[17] J. Arenas Gaitán, B. Peral Peral, and M. Ramón Jerónimo, "Elderly and internet banking: An application of UTAUT2," J. Internet Bank. Commer. 20 (1), 1-23., 2015.

[18] H. A. Widyanto, K. A. Kusumawardani, and A. Septyawanda, "Encouraging behavioral intention to use mobile payment: An extention of UTAUT2," J. Muara Ilmu Ekon. dan Bisnis, vol. 4, no. 1, pp. 87-97, 2020.

[19] P. T. M. Trang and N. H. Tho, "Perceived risk, investment performance and intentions in emerging stock markets," Int. J. Econ. Financ. Issues, vol. 7, no. 1, 2017.

[20] S. Annamalah, M. Raman, G. Marthandan, and A. K. Logeswaran, "An empirical study on the determinants of an investor's decision in unit trust investment," Economies, vol. 7, no. 3, p. 80, 2019.

[21] C. B. Foltz, H. E. Newkirk, and P. H. Schwager, "An empirical investigation of factors that influence individual behavior toward changing social networking security settings," J. Theor. Appl. Electron. Commer. Res., vol. 11, no. 2, pp. 1-15, 2016.

[22] A. O. I. Hoffmann, T. Post, and J. M. E. Pennings, "How investor perceptions drive actual trading and risk-taking behavior," J. Behav. Financ., vol. 16, no. 1, pp. 94-103, 2015.

[23] R. J. C. Yap, F. Komalasari, and I. Hadiansah, "The effect of financial literacy and attitude on financial management behavior and satisfaction," BISNIS BIROKRASI J. Ilmu Adm. dan Organ., vol. 23, no. 3, 2018.

[24] P. Mishra, "Modeling investment decision through perceived risk," Int. J. Eng. Adv. Technol., vol. 8 , no. $6 \mathrm{~S} 3,2019$.

[25] M. R. Tavakoli, F. Habibi Tanha, and N. Halid, "A study on small investors' behavior in choosing stock case study: Kuala-Lumpur stock market," African J. Bus. Manag., vol. 5, no. 27, pp. 11082-11092, 2011.

[26] M. Islamoğlu, M. Apan, and A. Ayvali, "Determination of factors affecting individual investor behaviours: A study on bankers," Int. J. Econ. Financ. Issues, vol. 5, no. 2, pp. 531-543, 2015.

[27] D. M. Rekha and S. Yashaswini, "Investors' attitude towards investment decisions in equity market," Int. J. Trend Sci. Res. Dev., vol. 3, 2019.

[28] K. Khoirunnisa and D. Priantinah, "Pengaruh norma subjektif, return ekpektasian dan modal investasi minimal terhadap minat investasi saham Mahasiswa Akuntansi Fakultas Ekonomi Universitas Negeri Yogyakarta," J. Profita Kaji. Ilmu Akunt., vol. 5, no. 8, 2017.

[29] Mathematics Learning Support Center, "Statistics: 1.1 Paired t-tests," Mathematics Learning $\begin{array}{llll}\text { Support Center, } & \text { [Online]. } & \text { Available: }\end{array}$ http://www.statstutor.ac.uk/resources/uploaded/paired-t-test.pdf.

[30] L. D. Utami and K. Kartini, "Faktor demografis, personality traits, dan overconfidence (Survey terhadap investor saham di Yogyakarta)," J. Siasat Bisnis, vol. 20, no. 2, p. 181, 2016.

[31] A. S. Mahardhika and T. Zakiyah, "Millennials' Intention in Stock Investment: Extended Theory of Planned Behavior," Ris. Akunt. dan Keuang. Indones., vol. 5, no. 1, pp. 83-91, 2020. 